\title{
Ti-bearing aenigmatite from Djinga Tadorgal (Adamawa plateau) and Sao Tomé (Cameroon Line) phonolites: geochemical implications and application of the QUILF thermobarometer for the crystallization conditions
}

\author{
Isaac Bertrand Gbambié MBOWOU ${ }^{1 *}$, Dagwaï NGUIHDAMA ${ }^{2}$, Fadimatou Ngounouno \\ YAMGOUOT $^{3}$, Mama NTOUMBE ${ }^{1}$ and Ismaïla NGOUNOUNO ${ }^{1}$ \\ ${ }^{1}$ Ecole de Géologie et d'Exploitation Minière (EGEM), Université de Ngaoundéré, B.P. 115, Meiganga, \\ Cameroun. \\ ${ }^{2}$ Département des Sciences de la Vie et de la Terre, Ecole Normale Supérieure, Université de Maroua, \\ B.P. 55, Maroua, Cameroun. \\ ${ }^{3}$ Faculté des Sciences, Université de Ngaoundéré, B.P. 454, Ngaoundéré, Cameroun. \\ *Corresponding author, E-mail: mbowou2000@yahoo.fr
}

\begin{abstract}
The chemical and structural compositions of aenigmatite from Djinga Tadorgal and Sao Tomé phonolites were compared to those previously described in the felsic lavas and nephelinite from the Adamawa Plateau and Cameroon Line, in order to determine their crystallization temperatures and pressures. Chemical analysis results and the application of QUILF thermobarometer, indicated the equilibrium temperatures between $655^{\circ} \mathrm{C}$ and $791{ }^{\circ} \mathrm{C}$, oxygen fugacity $\left(f \mathrm{O}_{2}\right)$ below the FMQ buffer, pressures near $0.1 \mathrm{GPa}$ and silica activities less than 1.0 for Djinga Tadorgal and Sao Tomé phonolites. The Ti-bearing aenigmatite from Djinga Tadorgal and Sao Tomé phonolites are a late and accessory mineral, resulting from the reaction between Tirich magnetite and $\mathrm{Na}_{2} \mathrm{O}$-rich magmatic liquid.
\end{abstract}

(C) 2013 International Formulae Group. All rights reserved.

Keywords: Peralkaline lavas, mineral chemistry, silica activity, thermodynamic conditions.

\section{INTRODUCTION}

Djinga Tadorgal is a stratovolcano (altitude: $1747 \mathrm{~m}$ ), located northern of the Congo Craton (western sector of the Adamawa plateau). Sao Tomé is an island (altitude: $2024 \mathrm{~m}$ ) of the Gulf of Guinea (Figure 1), ocean sector of the Cameroon Line. Cameroon Line, recently considered as "Cameroon Hot Line" (Déruelle et al., 2007), and Adamawa plateau are tectono-magmatic structures, respectively oriented $\mathrm{N} 30^{\circ} \mathrm{E}$ and $\mathrm{N} 70^{\circ} \mathrm{E}$ (Figure 1). The Djinga Tadoral stratovolcano consisting of trachytic and phonolitic lavas, and several basaltic flow units (Mbowou et al., 2010), is a volcanic complex. Sao Tomé Island is essentially characterized by the occurrence of basaltic and felsic lavas associated with palagonotic tuffs (Caldeira et al., 2004).

Aenigmatite crystals were previously described in felsic lavas (trachytes, phonolites, rhyolites) and nephelinites from both Adamawa plateau (Ngaoundere) (Temdjim et al., 2004; Nkouandou et al., 2008) and 
"Cameroon Hot Line" [Oku (Lissom, 1991); Mts Bambouto-Bamenda (N'ni, 2004); Mt Bamenda (Kamgang et al., 2007); Rumpi Mt (Nkoumbou, 1990); Mt Etinde (Nkoumbou et al., 1995); Kapsiki plateau (Ngounouno et al., 1997); Benue Valley (Ngounouno et al., 2003)]. Firstly discovered and analyzed from the nepheline-bearing syenite by Breithaupt (1866); these crystals of the triclinic system and belonging to aenigmatite-rhönite group (Kunzmann, 1999) are rare in felsic alkaline or peralkaline lavas, produced by differentiation of basaltic magma in continental or oceanic domains (Grapes et al., 1979).

The objective of this first description of the aenigmatite from Djinga Tadorgal strato-volcano and Sao Tomé volcanic island was to compare their chemical and structural compositions, to those of felsic alkaline lavas and nephelinite from other parts of the Adamawa plateau and the Cameroon Line, in order to identify the petrologic implications and thermodynamic conditions of crystallization of this mineral.

\section{MATERIALS AND METHODS}

Mineral phases (aenigmatite, clinopyroxene, Fe-Ti oxides, feldspar, nepheline) analyses were performed on the electron microprobes CAMEBAX SX50 and SX100 at the 'Université Pierre-et-Marie Curie, Paris'. The measurements were made according to standard analyzed data, under the conditions expressed in $\mathrm{kV}$ (accelerating voltage), nA (beam current) and s (counting times at the peak). Aenigmatite $(15 \mathrm{kV}, 40 \mathrm{nA}$, $10 \mathrm{~s}$ for $\mathrm{Si}$ and $\mathrm{Fe}, 15 \mathrm{~s}$ for $\mathrm{Ca}$ and $20 \mathrm{~s}$ for all other elements, clinopyroxene $(15 \mathrm{kV}, 40 \mathrm{nA}$, $20 \mathrm{~s}$ for $\mathrm{Si}, \mathrm{Al}, \mathrm{Fe}, \mathrm{Mg}, \mathrm{Ca}, \mathrm{Na}, \mathrm{Mn}$ and $30 \mathrm{~s}$ for $\mathrm{Ti}$ and $\mathrm{Zr}), \mathrm{Fe}-\mathrm{Ti}$ oxides $(15 \mathrm{kV}, 40 \mathrm{nA}$, $40 \mathrm{~s}$ for $\mathrm{Ti}, \mathrm{Fe}, \mathrm{Mn}, \mathrm{Mg} ; 10 \mathrm{~s}$ for $\mathrm{Si}, 15 \mathrm{~s}$ for $\mathrm{Cr}$ and $30 \mathrm{~s}$ for $\mathrm{Al})$, feldspar and nepheline $(15 \mathrm{kV}, 10 \mathrm{nA}, 5 \mathrm{~s}$ for all elements).
Measurements correction was carried out using the "PAP" program (Pouchou and Pichoir 1991). Analyses are given in terms of oxides of the elements (wt. $\%=$ weight $\%$ ).

Whole-rocks chemical analysis of phonolites (Table 2) was performed at the 'Centre de Recherches Pétrographiques et Géochimiques' (CRPG) of Nancy (France), where the samples were previously selected in order to limit superficial contamination, then crushed. Details of other analytical processes were presented elsewhere (Carignan et al., 2001). Major elements compositions were determined by inductively coupled plasma-atomic emission spectrometry (ICPAES). Precision is $0.5 \%$ for major element oxides.

The program QUILF95 (Andersen et al., 1993) called QUILF thermobarometer (White et al., 2005; Ren et al., 2006) has been used in application for the Djinga Tadorgal and Sao Tomé phonolites, to determine their thermodynamic conditions of crystallization during the eruption. For each sample, two calculations were performed, one with pressure (P) fixed at $0.1 \mathrm{GPa}$ while the silica activity $\left(\mathrm{aSiO}_{2}\right)$ was allowed to float (i.e., set as a trial value), and the other with $\mathrm{aSiO}_{2}$ fixed at 0.1 and 0.2 while the temperature $(\mathrm{T})$ was allowed to float. The minerals used (clinopyroxene, Fe-Ti oxide) for calculations, had not known subsolidus re-equilibrium as showed by their unzoned and homogeneous compositions (Table 2). The $\mathrm{aSiO}_{2}$ (quartz saturation) varied with pressure and the temperature determined from clinopyroxene$\mathrm{Fe}-\mathrm{Ti}$ oxide equilibria was strongly pressure (P)-dependent. Thus, if either $\mathrm{aSiO}_{2}$ or $\mathrm{P}$ is fixed, the other may be calculated if $\mathrm{T}$ is known with QUILF. Oxygen fugacity $\left(f \mathrm{O}_{2}\right)$ can also be calculated and even $\triangle F M Q=$ $\log \mathrm{O}_{2}-\mathrm{FMQ}(\mathrm{T}, \mathrm{P})$. 


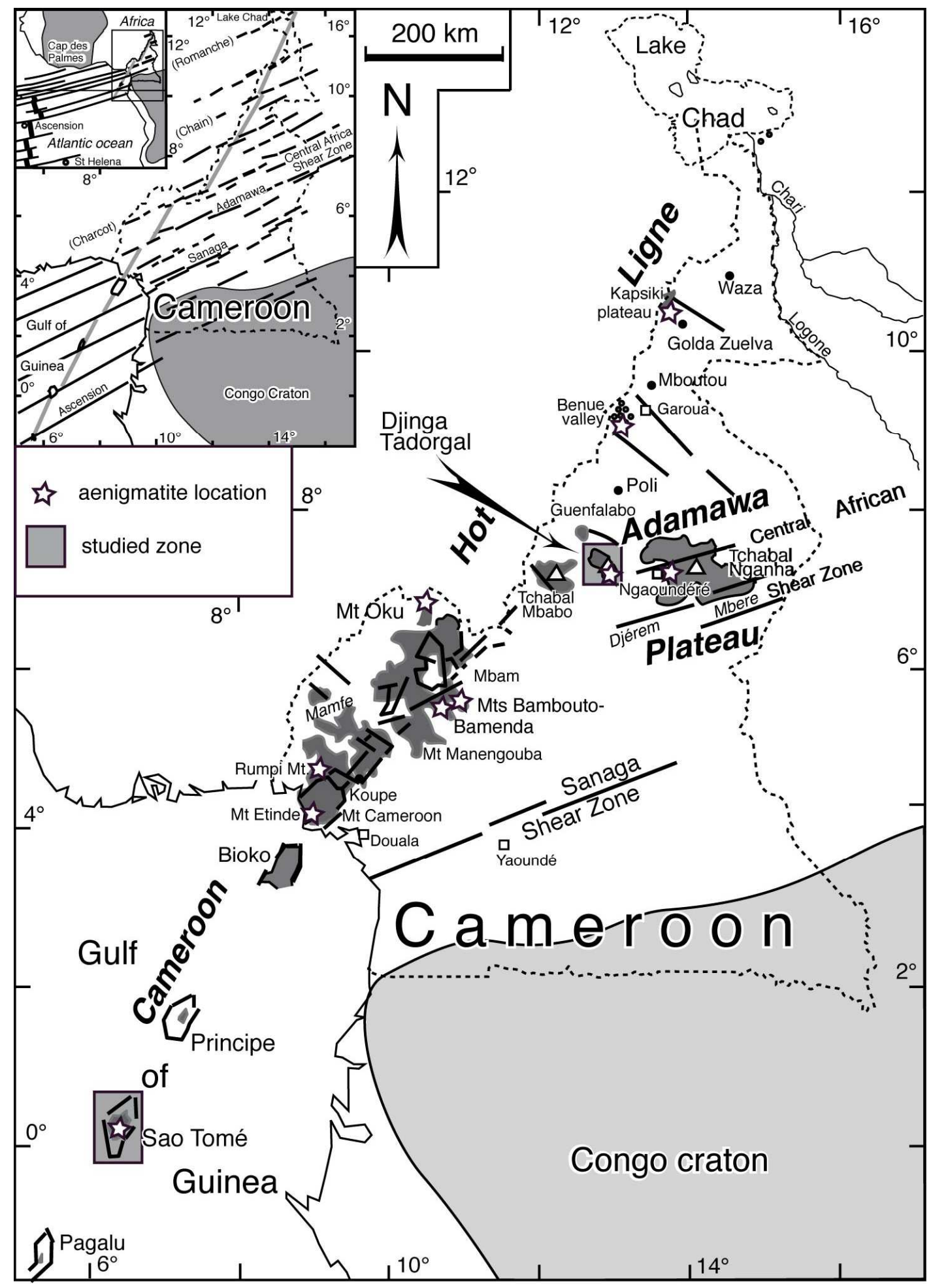

Figure 1: Location of the studied zone, sampling sites of aenigmatite-bearing rocks and tectonomagmatic settings of the "Cameroon Hot Line" and the Adamawa plateau (Déruelle et al., 2007). 


\section{RESULTS}

\section{Petrography of phonolites}

The phonolites from Djinga Tadorgal and Sao Tomé are porphyritic laves with a fluidal aspect, which consisted of sanidineanorthoclase (up to 4 vol. $\%=$ volume $\%$ ), aegirine augite $(\sim 1.5 \mathrm{vol} . \%)$, aegirine $(\sim 0.5$ vol.\%), aenigmatite ( 1 vol.\%), nepheline ( 3 vol.\%) and Ti-magnetite ( 2 vol.\%) phenocrysts, in a groundmass ( $\sim 8 \mathrm{vol} . \%)$ of the same microlitic crystals. Aenigmatite phenocrysts are reddish brown and show Timagnetite inclusions. Aenigmatite microlites occur sometimes as small interstitial crystals between the slats and microcrystals of aegirine and sanidine-anorthoclase.

\section{Chemical characteristics of aenigmatite}

The $\mathrm{TiO}_{2^{-}}$(up to 8.7 wt.\%) and $\mathrm{Na}_{2} \mathrm{O}$ (up to $7.1 \mathrm{wt} . \%$ ) rich aenigmatite from Djinga Tadorgal and Sao Tomé, showed high $\mathrm{FeO} *$ contents (up to 40.5 wt.\%) and low $\mathrm{CaO}$ (< 0.7 wt. \%). $\mathrm{FeO}^{*}$ contents of aenigmatite from Oku reaching 42.8 wt. $\%$. However, $\mathrm{TiO}_{2}$ contents of the aenigmatite from the felsic lavas of $\mathrm{Oku}\left(\mathrm{TiO}_{2}\right.$ : up to 8.5 wt.\%), Mts Bambouto $\left(\mathrm{TiO}_{2}\right.$ : up to $\left.8.1 \mathrm{wt} . \%\right)$, Rumpi Mt $\left(\mathrm{TiO}_{2}\right.$ : up to 8.4 wt.\%) and Ngaoundéré $\left(\mathrm{TiO}_{2}\right.$ : 6.4 wt. $\%)$ are similar close to those from Djinga Tadorgal and Sao Tomé (Table 1). $\mathrm{Na}_{2} \mathrm{O}$ contents for the aenigmatite from the Djinga Tadorgal and Sao Tomé (Figure 2) have more or less the same behavior as those of the whole Adamawa plateau $\left(\mathrm{Na}_{2} \mathrm{O}\right.$ : up to 7.0 wt.\%) and "Cameroon Hot Line" $\left(\mathrm{Na}_{2} \mathrm{O}\right.$ : up to $7.6 \mathrm{wt} . \%$; Table 1$)$.

High $\mathrm{Fe}^{3+}(0.4-0.9$ apfu) contents in aenigmatite from Djinga Tadorgal and Sao Tomé were characterized by the presence of $\mathrm{Fe}^{3+}$-Tschermak (up to $4 \%$ ), $\mathrm{Fe}^{3+}$-aenigmatite (up to $23 \%$ ) and $\mathrm{Fe}^{3+}$ - $\mathrm{Al}$ aenigmatite (up to $34 \%$ ) components in their respective sites, like those of other aenigmatites of the Cameroon Line and the Adamawa Plateau. The aenigmatite is a silicate chain of theoretical formula: $\mathrm{X}^{\mathrm{VIII}}{ }_{2} \mathrm{Y}^{\mathrm{VI}}{ }_{6} \mathrm{Z}_{6}{ }_{6} \mathrm{O}_{20}$ with $\mathrm{X}=\mathrm{Na}^{+}, \mathrm{Ca}^{2}$ ${ }^{+} ; \mathrm{Y}=\mathrm{Mg}^{2+}, \mathrm{Fe}^{2+}, \mathrm{Fe}^{3+}, \mathrm{Ti}^{4+}, \mathrm{Al}^{3+}, \mathrm{Mn}^{2+}, \mathrm{Cr}^{3+}$, $\mathrm{Ti}^{3+}, \mathrm{Ca}^{2+}, \mathrm{Sb}^{5+} \mathrm{Nb}^{5+} \mathrm{As}^{5+}$ and $\mathrm{Z}=\mathrm{Si}^{4+}, \mathrm{Al}^{3+}$, $\mathrm{Fe}^{3+}, \mathrm{Be}^{2+}, \mathrm{B}^{3+}$. The distribution of major elements of the Sao Tomé and Djinga Tadorgal aenigmatite is illustrated by the histograms (Figure 3), referring to the structural formula. Apart from the high $\mathrm{Al}^{\mathrm{IV}}$ (up to $0.40 \mathrm{apfu}$ ) and $\mathrm{Mg}^{\mathrm{VI}}$ (up to $0.24 \mathrm{apfu}$ ) contents in the aenigmatite from Sao Tomé and Djinga Tadorgal respectively, the behavior of all other major elements were similar, even for the formerly studied Cameroon Line aenigmatite phases than for the Adamawa Plateau.

\section{Thermodynamic conditions of crystallization \\ QUILF thermobarometer results for $\mathrm{T}$,} $\mathrm{P}, f \mathrm{O}_{2}$, and $\mathrm{aSiO}_{2}$ are summarized in Table 3 and Figure 4. It suggests equilibrium temperatures between $655{ }^{\circ} \mathrm{C}$ and $791{ }^{\circ} \mathrm{C}$ for Djinga Tadorgal and Sao Tomé samples, oxygen fugacity below the FMQ buffer, pressures near $0.1 \mathrm{GPa}$, and silica activity less than 1.0. These thermobarometric results are likely the magmatic conditions few times before the eruption of the Djinga Tadorgal and Sao Tomé phonolitic lavas and also likely the magmatic condition during the crystallization of aenigmatite (Figure 4). Thus, these magmatic conditions could be considered as the stability domain of the aenigmatite, which crystallized in the Djinga Tadorgal and Sao Tomé samples with the other phases as showed by the petrographic observations. 


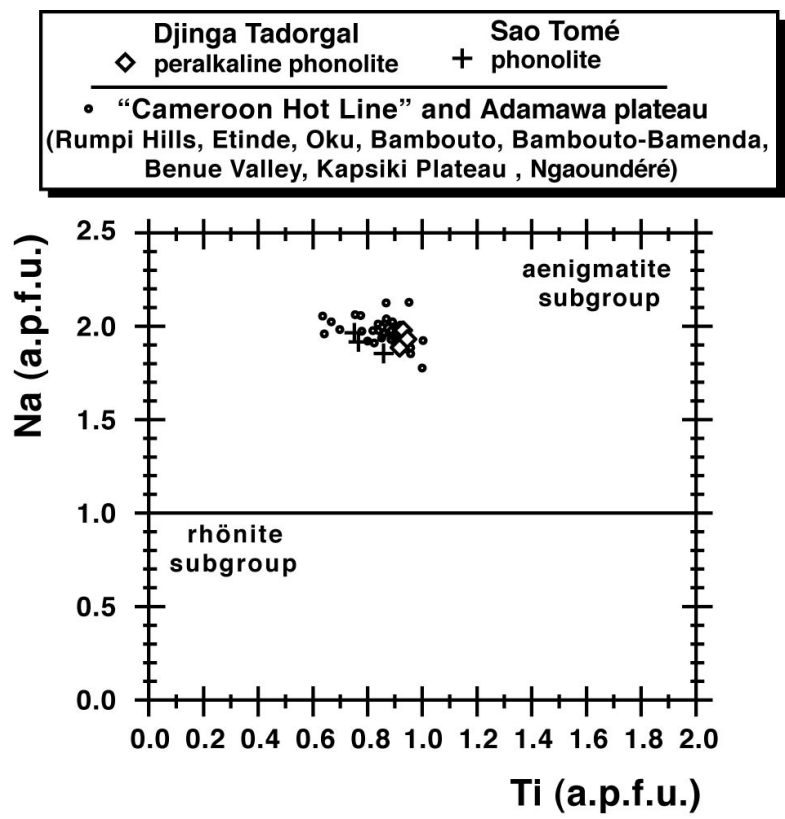

Figure 2: Differentiation of aenigmatite and rhönite subgroups. The compositions of the Djinga Tadorgal and Sao Tomé aenigmatite are represented in comparison to those of other areas of the Adamawa plateau and the "Cameroon Hot Line" (see text for references).

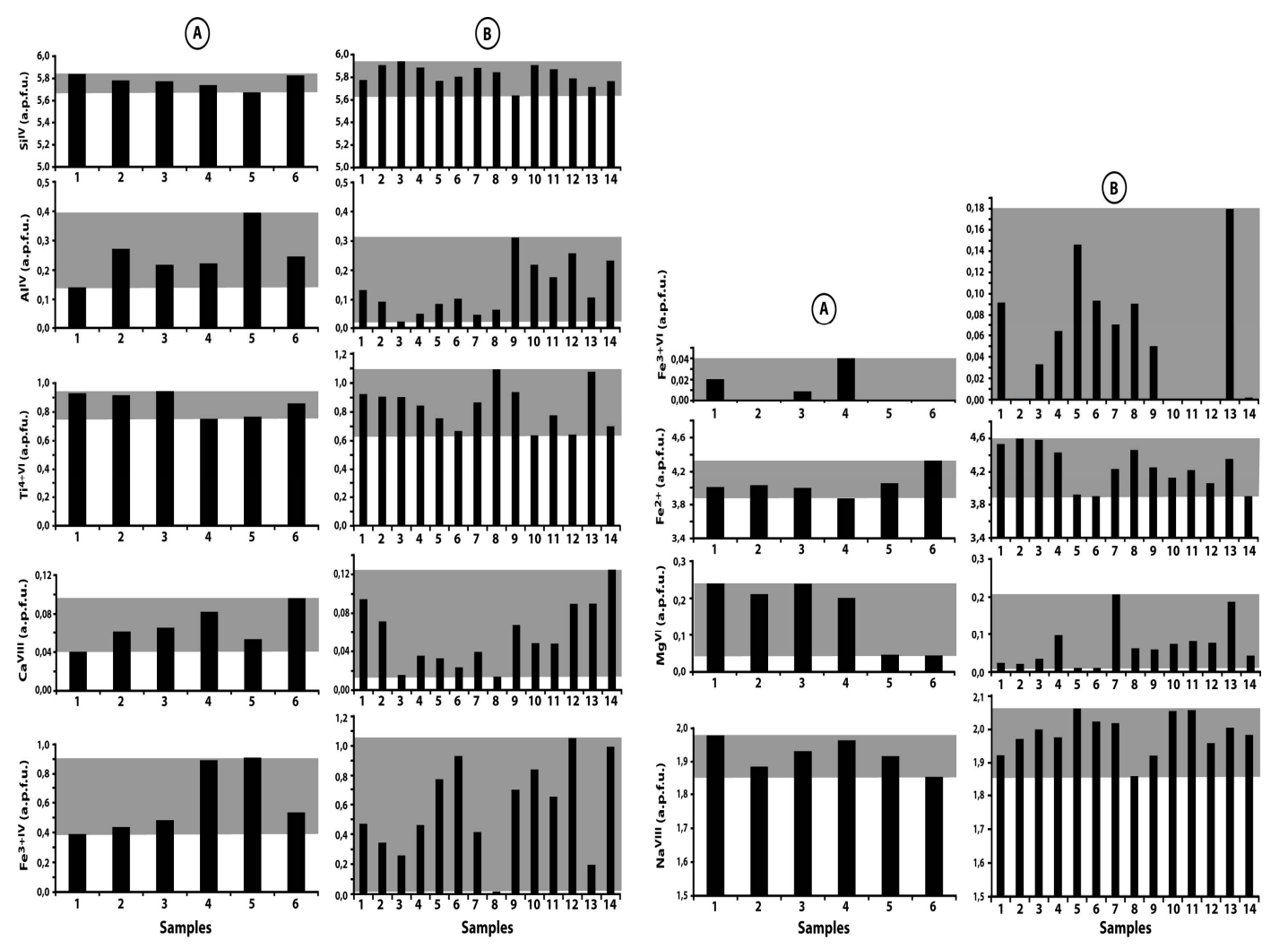

Figure 3: Distribution of major elements in the histograms, refering to the structural formula of aenigmatite. (a) Djinga Tadorgal and Sao Tomé, (b) other areas of the Adamawa plateau and the "Cameroon Hot Line". 


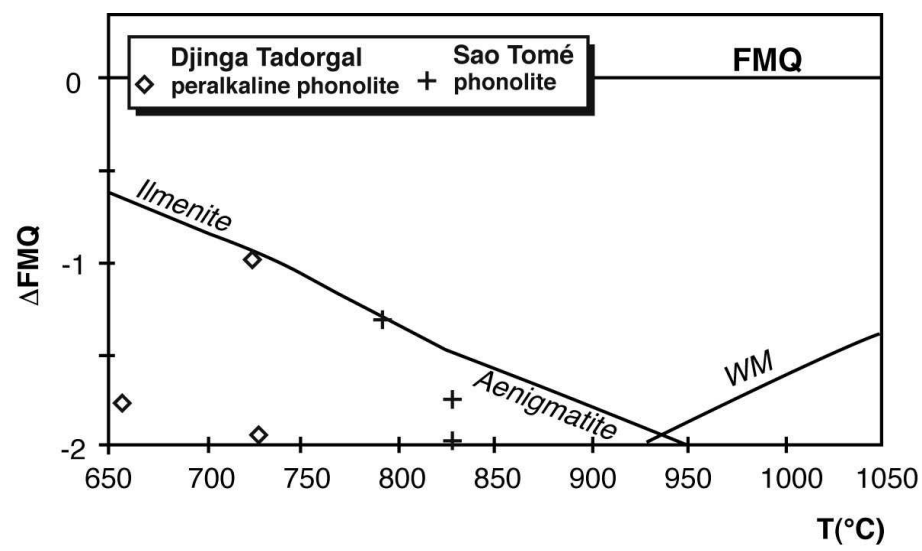

Figure 4: Temperature and oxygen fugacity data from the Djinga Tadorgal and Sao Tomé phonolites with the aenigmatite-Ilmenite and wüstite-magnetite (WM) stability curves (White et al., 2005) plotted relatively to the FMQ buffer ( $\triangle$ FMQ; Frost et al., 1988).

Table 1: Representative chemical compositions and structural formula (formula proportions based on 14 cations and 20 oxygens) of aenigmatite from Adamawa Plateau and the "Cameroon Hot Line" lavas.

\begin{tabular}{|c|c|c|c|c|c|c|c|c|c|}
\hline \multirow{3}{*}{$\begin{array}{l}\text { Location } \\
\text { Lava type } \\
\text { Sample } \\
\end{array}$} & \multirow{2}{*}{\multicolumn{3}{|c|}{$\begin{array}{c}\text { Djinga Tadorgal } \\
\text { Peralkal. } \\
\text { Phonolite } \\
\end{array}$}} & \multirow{2}{*}{\multicolumn{3}{|c|}{$\begin{array}{l}\text { Sao Tomé } \\
\text { Phonolite }\end{array}$}} & \multicolumn{3}{|c|}{ Oku } \\
\hline & & & & & & & & hyolite & \\
\hline & DT113 & & & ST44 & & & LJ04E & & \\
\hline $\mathrm{SiO}_{2}$ (wt.\%) & 40.42 & 40.05 & 40.10 & 39.58 & 38.73 & 39.93 & 39.95 & 40.54 & 40.96 \\
\hline $\mathrm{TiO}_{2}$ & 8.56 & 8.44 & 8.73 & 6.90 & 6.96 & 7.82 & 8.48 & 8.25 & 8.26 \\
\hline $\mathrm{Al}_{2} \mathrm{O}_{3}$ & 0.83 & 1.60 & 1.29 & 1.30 & 2.29 & 1.43 & 0.78 & 0.54 & 0.15 \\
\hline $\mathrm{FeO}^{*}$ & 36.58 & 37.00 & 37.30 & 39.67 & 40.53 & 39.88 & 42.13 & 40.57 & 40.21 \\
\hline $\mathrm{MnO}$ & 4.09 & 4.17 & 3.96 & 2.99 & 2.98 & 2.91 & 1.02 & 1.20 & 1.69 \\
\hline $\mathrm{MgO}$ & 1.11 & 0.98 & 1.11 & 0.93 & 0.21 & 0.20 & 0.11 & 0.10 & 0.16 \\
\hline $\mathrm{CaO}$ & 0.26 & 0.40 & 0.43 & 0.53 & 0.34 & 0.62 & 0.61 & 0.46 & 0.10 \\
\hline $\mathrm{Na}_{2} \mathrm{O}$ & 7.07 & 6.74 & 6.92 & 6.99 & 6.75 & 6.56 & 6.86 & 6.98 & 7.11 \\
\hline $\mathrm{K}_{2} \mathrm{O}$ & 0.04 & 0.43 & 0.00 & 0.07 & 0.43 & 0.07 & & 0.02 & 0.08 \\
\hline Sum & 98.96 & 99.80 & 99.84 & 98.95 & 99.23 & 99.42 & 99.94 & 98.66 & 98.72 \\
\hline Si (apfu) & 5.838 & 5.780 & 5.773 & 5.738 & 5.672 & 5.827 & 5.775 & 5.906 & 5.941 \\
\hline $\mathrm{Ti}$ & 0.930 & 0.917 & 0.945 & 0.752 & 0.767 & 0.858 & 0.922 & 0.904 & 0.901 \\
\hline $\mathrm{Al}$ & 0.141 & 0.272 & 0.218 & 0.222 & 0.395 & 0.246 & 0.133 & 0.093 & 0.026 \\
\hline $\mathrm{Fe}^{3+\mathrm{VI}}$ & 0.389 & 0.436 & 0.483 & 0.893 & 0.911 & 0.535 & 0.469 & 0.344 & 0.259 \\
\hline $\mathrm{Fe}^{3+\mathrm{IV}}$ & 0.020 & 0.000 & 0.009 & 0.040 & 0.000 & 0.000 & 0.092 & 0.001 & 0.033 \\
\hline $\mathrm{Fe}^{2+}$ & 4.009 & 4.029 & 3.999 & 3.875 & 4.052 & 4.330 & 4.532 & 4.597 & 4.585 \\
\hline $\mathrm{Mn}$ & 0.500 & 0.510 & 0.483 & 0.367 & 0.370 & 0.360 & 0.125 & 0.148 & 0.208 \\
\hline $\mathrm{Mg}$ & 0.240 & 0.211 & 0.239 & 0.201 & 0.046 & 0.044 & 0.024 & 0.022 & 0.035 \\
\hline $\mathrm{Ca}$ & 0.040 & 0.061 & 0.066 & 0.082 & 0.053 & 0.096 & 0.094 & 0.072 & 0.016 \\
\hline $\mathrm{Na}$ & 1.979 & 1.886 & 1.932 & 1.964 & 1.917 & 1.854 & 1.923 & 1.971 & 1.999 \\
\hline $\mathrm{K}$ & 0.008 & 0.080 & 0.000 & 0.013 & 0.080 & 0.013 & & 0.004 & 0.015 \\
\hline Rhönite (mol.\%) & 2.0 & 3.1 & 3.3 & 4.1 & 2.7 & 4.8 & 4.7 & 3.6 & 0.8 \\
\hline $\mathrm{Fe}^{3+}-\mathrm{Al}$ aenigmatite & 10.1 & 21.1 & 15.2 & 14.0 & 34.2 & 15.0 & 3.8 & 2.1 & 1.0 \\
\hline $\mathrm{Fe}^{3+}-$ Tschermak & 2.0 & 0.0 & 0.9 & 4.0 & 0.0 & 0.0 & 9.2 & 0.1 & 3.3 \\
\hline $\mathrm{Fe}^{3+}$ aenigmatite & 7.0 & 8.3 & 5.5 & 24.8 & 23.3 & 14.2 & 7.8 & 9.6 & 9.9 \\
\hline Ideal aenigmatite & 78.8 & 67.5 & 75.1 & 53.1 & 39.8 & 66.1 & 74.5 & 84.6 & 85.0 \\
\hline
\end{tabular}




\begin{tabular}{|c|c|c|c|c|c|c|c|c|}
\hline Location & Benue & Bamboutos & Bamenda & \multicolumn{3}{|c|}{ Rumpi Mt. } & Mt. Etinde & Ngaoundéré \\
\hline Lava type & $\begin{array}{l}\text { Peralkal. } \\
\text { Trachyte }\end{array}$ & Phonolite & $\begin{array}{l}\text { Peralkal. } \\
\text { phonolite }\end{array}$ & \multicolumn{3}{|c|}{ Phonolite } & Néphélinite & Phonolite \\
\hline Sample & MU1 & B5 & CA317 & \multicolumn{2}{|c|}{ CN44 } & & M146 & NG16 \\
\hline $\mathrm{SiO}_{2}$ (wt.\%) & 39.69 & 41.40 & 40.37 & 38.17 & 40.47 & 40.83 & 40.06 & 39.56 \\
\hline $\mathrm{TiO}_{2}$ & 6.90 & 8.09 & 10.23 & 8.42 & 5.79 & 7.16 & 10.04 & 6.37 \\
\hline $\mathrm{Al}_{2} \mathrm{O}_{3}$ & 0.50 & 0.29 & 0.50 & 1.79 & 1.27 & 1.04 & 0.64 & 1.36 \\
\hline $\mathrm{MnO}$ & 4.03 & 2.04 & 4.26 & 2.15 & 1.98 & 1.94 & 1.27 & 3.32 \\
\hline $\mathrm{MgO}$ & 0.05 & 0.98 & 0.34 & 0.27 & 0.34 & 0.38 & 0.88 & 0.20 \\
\hline $\mathrm{CaO}$ & 0.21 & 0.26 & 0.14 & 0.43 & 0.31 & 0.31 & 0.59 & 0.80 \\
\hline $\mathrm{Na}_{2} \mathrm{O}$ & 7.32 & 7.33 & 7.56 & 6.71 & 7.26 & 7.38 & 7.25 & 7.02 \\
\hline $\mathrm{K}_{2} \mathrm{O}$ & 0.03 & 0.03 & & 0.00 & & 0.00 & 0.05 & \\
\hline $\mathrm{Fe}^{3+\mathrm{VI}}$ & 0.775 & 0.414 & 0.015 & 0.698 & 0.842 & 0.649 & 0.196 & 0.995 \\
\hline $\mathrm{Fe}^{3+\mathrm{IV}}$ & 0.146 & 0.070 & 0.091 & 0.050 & 0.000 & 0.000 & 0.180 & 0.002 \\
\hline $\mathrm{Fe}^{2+}$ & 3.920 & 4.236 & 4.463 & 4.256 & 4.121 & 4.223 & 4.355 & 3.901 \\
\hline Mn & 0.496 & 0.246 & 0.537 & 0.269 & 0.245 & 0.236 & 0.153 & 0.410 \\
\hline $\mathrm{Mg}$ & 0.011 & 0.207 & 0.062 & 0.059 & 0.074 & 0.081 & 0.187 & 0.043 \\
\hline $\mathrm{Ca}$ & 0.033 & 0.040 & 0.014 & 0.068 & 0.048 & 0.048 & 0.090 & 0.125 \\
\hline $\mathrm{Na}$ & 2.062 & 2.019 & 1.860 & 1.922 & 2.054 & 2.057 & 2.004 & 1.983 \\
\hline $\mathrm{K}$ & 0.006 & 0.006 & & 0.000 & & 0.000 & 0.009 & \\
\hline Rhönite (mol.\%) & 1.6 & 2.0 & 0.7 & 3.4 & 2.4 & 2.4 & 4.5 & 6.2 \\
\hline $\mathrm{Fe}^{3+}-\mathrm{Al}$ aenigmatite & 5.3 & 0.8 & 5.2 & 24.4 & 17.0 & 12.8 & 1.7 & 10.9 \\
\hline
\end{tabular}

Table 2: Representative compositions of clinopyroxene and Fe-Ti oxide from Djinga Tadorgal and Sao Tomé phonolites.

\begin{tabular}{|c|c|c|c|c|}
\hline \multirow{2}{*}{\begin{tabular}{|l|} 
Minerals \\
Sample \\
\end{tabular}} & \multicolumn{2}{|c|}{ Clinopyroxene } & \multicolumn{2}{|l|}{ Fe-Ti oxide } \\
\hline & DT113 & ST44 & DT113 & ST44 \\
\hline $\mathrm{SiO}_{2}$ (wt.\%) & 51.510 & 51.770 & 0.010 & 0.000 \\
\hline $\mathrm{TiO}_{2}$ & 2.340 & 2.420 & 23.210 & 22.320 \\
\hline $\mathrm{Al}_{2} \mathrm{O}_{3}$ & 0.630 & 0.690 & 0.070 & 0.140 \\
\hline $\mathrm{FeO}$ & 21.40 & 24.910 & 69.520 & 70.410 \\
\hline $\mathrm{MnO}$ & 1.810 & 1.200 & 5.340 & 4.900 \\
\hline $\mathrm{MgO}$ & 3.090 & 0.100 & 0.090 & 0.250 \\
\hline $\mathrm{CaO}$ & 9.400 & 7.200 & 0.000 & 0.000 \\
\hline $\mathrm{Na}_{2} \mathrm{O}$ & 8.490 & 9.410 & & \\
\hline $\mathrm{ZrO}_{2}$ & & 1.320 & & \\
\hline Total & 98.670 & 99.020 & 98.240 & 98.020 \\
\hline En (mol.\%) & 0.287 & 0.013 & & \\
\hline Wo & 0.456 & 0.421 & & \\
\hline $\mathrm{Hem}$ (mol.\%) & & & 0.564 & 0.580 \\
\hline Gk & & & 0.003 & 0.093 \\
\hline
\end{tabular}


Table 3: Results of QUILF thermobarometer calculations for Djinga Tadorgal and Sao Tomé samples.

\begin{tabular}{llcccccc}
\hline Location & \multicolumn{3}{c}{ Djinga Tadorgal } & \multicolumn{3}{c}{ Sao Tomé } \\
\hline En $(\mathrm{mol} . \%)$ & & 0.287 & 0.287 & 0.287 & 0.013 & 0.013 & 0.013 \\
$\mathrm{Wo}$ & & 0.456 & 0.456 & 0.456 & 0.421 & 0.421 & 0.421 \\
$\mathrm{Hem}(\mathrm{mol} \%)$ & & 0.564 & 0.564 & 0.564 & 0.580 & 0.580 & 0.580 \\
$\mathrm{Gk}$ & & 0.003 & 0.003 & 0.003 & 0.093 & 0.093 & 0.093 \\
$\mathrm{~T}\left({ }^{\circ} \mathrm{C}\right)$ & Input & 727 & 727 & 725 & 827 & 727 & 827 \\
& Calc. & 655 & 725 & & & 791 & \\
$\mathrm{P}(\mathrm{GPa})$ & Input & 0.100 & 0.100 & 0.100 & 0.100 & 0.100 & 0.100 \\
& Calc. & 0.100 & 0.100 & & & 0.100 & \\
$\mathrm{aSiO}_{2}$ & Input & 0.100 & 0.100 & 0.800 & 0.200 & 0.200 & 0.400 \\
& Calc. & & & 0.178 & 0.172 & & 0.297 \\
$\log f \mathrm{O}_{2}$ & Input & -20.000 & -18.200 & -15.000 & -10.000 & -16.000 & -15.000 \\
& Calc. & & & -14.900 & -18.195 & & -14.985 \\
$\Delta \mathrm{FMQ}$ & & -1.941 & -1.934 & -0.962 & -1.981 & -1.287 & -1.748 \\
\hline
\end{tabular}

Table 4: Distribution of major elements in aenigmatite-bearing phonolites from Djinga Tadorgal and Sao Tomé.

\begin{tabular}{|c|c|c|}
\hline Lava types & P. Phonolite & Phonolite \\
\hline Sample & DT113 & ST44 \\
\hline $\mathrm{SiO}_{2}$ (wt.\%) & 62.64 & 61.68 \\
\hline $\mathrm{TiO}_{2}$ & 0.60 & 0.35 \\
\hline $\mathrm{Al}_{2} \mathrm{O}_{3}$ & 18.00 & 18.26 \\
\hline $\mathrm{Fe}_{2} \mathrm{O}_{3} *$ & 3.02 & 3.73 \\
\hline $\mathrm{MnO}$ & 0.19 & 0.21 \\
\hline $\mathrm{MgO}$ & 0.30 & 0.31 \\
\hline $\mathrm{CaO}$ & 0.93 & 1.25 \\
\hline $\mathrm{Na}_{2} \mathrm{O}$ & 7.30 & 6.78 \\
\hline $\mathrm{K}_{2} \mathrm{O}$ & 6.07 & 5.46 \\
\hline $\mathrm{P}_{2} \mathrm{O}_{5}$ & 0.10 & 0.06 \\
\hline L.O.I & 0.60 & 1.29 \\
\hline Sum & 99.75 & 99.38 \\
\hline $\mathrm{Na}_{2} \mathrm{O}+\mathrm{K}_{2} \mathrm{O}$ & 13.37 & 12.24 \\
\hline $\mathrm{TiO}_{2} / \mathrm{Fe}_{2} \mathrm{O}_{3} *$ & 0.20 & 0.09 \\
\hline D.I. & 93.42 & 89.11 \\
\hline P.I. & 1.03 & 0.93 \\
\hline mg\# & 0.26 & 0.17 \\
\hline
\end{tabular}

\section{DISCUSSION}

High $\mathrm{TiO}_{2}$ contents in the studied aenigmatite reflects a late crystallization. The low $\mathrm{Ca}(0.040-0.096 \mathrm{apfu})$ and $\mathrm{Al}(0.141-$ $0.395 \mathrm{apfu})$ contents in the chemical structure of the Djinga Tadorgal and Sao Tomé aenigmatite could be the result of the combined effect of the low temperature of crystallization and the high silica activity. The high $\mathrm{Fe}^{3+}$ contents characterized by the presence of $\mathrm{Fe}^{3+}$-Tschermak, $\mathrm{Fe}^{3+}$-aenigmatite and $\mathrm{Fe}^{3+}-\mathrm{Al}$ aenigmatite, indicate $f \mathrm{O}_{2}$ 
conditions, lower than those of the FMQ buffer. Low oxygen fugacity $\left(f \mathrm{O}_{2}\right)$ favors crystallization of Ti-aegirine. A sudden increasing of $\mathrm{fO}_{2}$ in felsic rocks would produce instability of aenigmatite and growth of $\mathrm{Na}$ contents in clinopyroxene, with crystallization of aegirine and aegirine augite (Njonfang and Nono, 2003). This suggests that the change of $\mathrm{fO}_{2}$ conditions during the crystallization, may explain the chemical and structural features of the Na-rich pyroxene (aegirine-augite, aegirine) and the aenigmatite crystals in felsic rocks.

On the basis of a generally antipathetic relationship between aenigmatite and FeTioxides, Nicholls and Carmichael (1969) proposed that aenigmatite crystallization is stabilized by the reaction of pyroxene and $\mathrm{Ti}$ rich oxides with Na-rich melt. They recognized a "no-oxide field" in $\mathrm{T}-f \mathrm{O}_{2}$ space in which aenigmatite is stable but the oxides are not. The aenigmatite can replace Fe-Ti oxides, which crystallize simultaneously or later with the sodic clinopyroxene. The phonolites from Djinga Tadorgal and Sao Tomé are alkali rich (more or less peralkaline) lavas $\left(\mathrm{Na}_{2} \mathrm{O}+\mathrm{K}_{2} \mathrm{O}: 12.2-13.4\right.$ wt.\%; P.I. = $\left[\left(\mathrm{Na}_{2} \mathrm{O}+\mathrm{K}_{2} \mathrm{O}\right) / \mathrm{Al}_{2} \mathrm{O}_{3}\right]: 0.93-1.03$; Table 4), but do not contain ilmenite and arfvedsonite crystals. Overall, there is a simple relationship between whole-rock peralkalinity and the degree of $(\mathrm{Al}+\mathrm{Ca})$ substitution. Mahood and Stimac (1990) noted that aenigmatite phenocrysts contain more $\mathrm{Na}$ and less $\mathrm{Al}$ and $\mathrm{Ca}$ as whole-rock P.I. increases. The development of peralkaline liquids (Ronga et al., 2010) is considerable when the $f_{2}$ is below FMQ buffer at the temperatures below $900{ }^{\circ} \mathrm{C}$. Abnormally low values of $\mathrm{Ti} / \mathrm{Fe}$ in felsic rocks are sometimes caused by the crystallization of Ti-bearing aenigmatite, as evidenced by the low values of $\mathrm{TiO}_{2} / \mathrm{FeO} *$ ratio $(0.09-0.20$; Table 1$)$ for the Djinga Tadorgal and Sao Tomé phonolites.

The Djinga Tadorgal and Sao Tomé aenigmatite could therefore be the product of the reaction between aegirine and $\mathrm{Ti}$ magnetite.

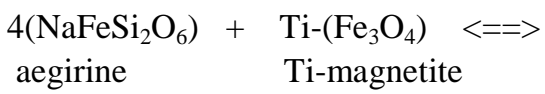

$\mathrm{Na}_{2} \mathrm{Fe}_{5} \mathrm{TiSi}_{6} \mathrm{O}_{20}+\left(\mathrm{Na}_{2} \mathrm{Si}_{2} \mathrm{O}_{5}, 2 \mathrm{FeO}\right)+1 / 2\left(\mathrm{O}_{2}\right)$. aenigmatite melt gas

However, Na-rich pyroxene (aegirine, aegirine augite) are known to occur at low temperature $\left(<600{ }^{\circ} \mathrm{C}\right)$ and under low $f \mathrm{O}_{2}$. According to White et al., (2005) which described the stability of aenigmatite relative to ilmenite (Ti-rich oxides) as a function of $\mathrm{T}$ and $f \mathrm{O}_{2}$, proposed the equation below :

$\mathrm{Na}_{2} \mathrm{Si}_{2} \mathrm{O}_{5}+4 \mathrm{SiO}_{2}+\left(2 \mathrm{Fe}_{2} \mathrm{O}_{3}+\mathrm{FeTiO}_{3}\right)=$ melt quartz ilmenites.s.

$\mathrm{Na}_{2} \mathrm{Fe}_{5} \mathrm{TiSi}_{6} \mathrm{O}_{20}+\mathrm{O}_{2}$

aenigmatite gas

It appears that aenigmatite stability is a function of both $\mathrm{fO}_{2}$ and $\mathrm{aSiO}_{2}$. Although the stability field of aenigmatite expands at lower $\mathrm{fO}_{2}$, it also requires relatively high silica activities, particularly at $\mathrm{T}>750{ }^{\circ} \mathrm{C}$, and is overall more stable at lower temperatures (Macdonald et al., 2011). The crystallization of Ti-bearing aenigmatite is therefore probably the result of the reaction between the Ti-rich oxides and $\mathrm{Na}_{2} \mathrm{O}$-rich magmatic liquid, as attested by the presence of Ti-magnetite inclusions in Djinga Tadorgal and Sao Tomé aenigmatites.

\section{Conclusion}

The characteristics of the Ti-bearing aenigmatite from Djinga Tadorgal and Sao Tomé phonolites are more or less similar to those of the felsic lavas from other parts of the Adamawa plateau and the Cameroon Line. Aenigmatie is a late and accessory mineral, exclusively present in more or less peralkaline rocks (Avanzinelli et al., 2004). As showed by QUILF calculations, the Djinga Tadorgal and Sao Tomé phonolites were erupted at very low $f \mathrm{O}_{2}$ below FMQ buffer, after the occurrence of Ti-bearing aenigmatite. Ti-bearing aenigmatite is the product of the reaction between $\mathrm{Fe}-\mathrm{Ti}$ oxides and $\mathrm{Na}_{2} \mathrm{O}$ rich magmatic liquid. It stability is most likely 
temperature- and $f \mathrm{O}_{2}$-dependent, at $\sim 0.1 \mathrm{GPa}$. $\mathrm{fO}_{2}$ affect clinopyroxene stability and composition. As discussed, Aegirine and other Na-bearing phases such as aenigmatite played an important role in the formation of Djinga Tadorgal and Sao Tomé phonolites. Aenigmatite was consequently stable in the studied phonolites under low $\mathrm{fO}_{2}$ conditions, low temperature $\left(<800{ }^{\circ} \mathrm{C}\right)$ and low pressure $(\sim 0.1 \mathrm{GPa})$.

\section{ACKNOWLEDGEMENTS}

The French 'Ministère de la Coopération' is acknowledged for providing a grant to I.B.M.G. for nine-month stay in France in the 'Laboratoire de magmatologie et de géochimie inorganique et expérimentale, Université Pierre-et-Marie-Curie', Paris, and to Bernard Déruelle for scientific support for this study.

\section{REFERENCES}

Andersen DJ, Lindsley D, Davidson PM. 1993. QUILF: A PASCAL program to assess equilibria among $\mathrm{Fe}-\mathrm{Mg}-\mathrm{Mn}-\mathrm{Ti}$ oxides, pyroxenes, olivine, and quartz. Comp. Geosciences, 19: 1333-1350.

Avanzinelli R, Bindi L, Menchetti S, Conticelli S. 2004. Crystallisation and genesis of peralkaline magmas from Pantelleria Volcano, Italy: an integrated petrological and crystal-chemical study. Lithos, 73: 41-69.

Breithaupt A. 1866. Mineralogische Studien. Berg- und hüttenmännische Zeitung. Freiberg, Leipzig, 24: 397-398.

Caldeira R, Munhá JM, Madeira J, Afonso R, Nascimento E, Mata J. 2004. Geological map of São Tomé Island, Gulf of Guinea: a management tool towards sustainable development. $20^{\text {th }}$ colloquium of African Geology, Orleans, France, Abstracts volume, p. 103.

Carignan J, Hild P, Mévelle G, Morel J, Yeghicheyan D. 2001. Routine analyses of trace elements in geological samples using flow injection and low pressure on-line liquid chromatography couples to ICPMS : a study of geochemical reference materials BR. DR-N, UB-N, AN-G and GH. Geostandards Newslett, 25: $187-198$.

Déruelle B, Ngounouno I, Demaiffe D. 2007. The "Cameroon Hot Line" (CHL): A unique example of active alkaline intraplate structure in both oceanic and continental lithospheres. C.R. Geoscience, 339: 589-600.

Grapes R, Yagi K, Okumura K. 1979. Aenigmatite, sodic pyroxene, arfvedsonite and associated minerals in syenites from Morotu, Sakhalin. Contrib. Mineral. Petrol., 69: 97-103.

Kamgang P, Njonfang E, Chazot G, Tchoua F. 2007. Géochimie et géochronologie des laves felsiques des monts Bamenda (ligne volcanique du Cameroun). C.R. Geoscience, 339: 659-666.

Kunzmann T. 1999. The aenigmatite-rhönite mineral group. Eur. J. Mineral., 11: 743-756.

Lissom J. 1991. Étude pétrologique des laves alcalines du massif d'Oku: un ensemble volcanique de la "Ligne du Cameroun". Thèse Doctorat, Université Pierre-etMarie-Curie, Paris 6., p. 129.

Macdonald R, Bagiński B, Leat PT, White JC, Dzierżanowski P. 2011. Mineral stability in peralkaline silicic rocks: Information from trachytes of the Menengai volcano, Kenya, Lithos, 125: 553-568.

Mahood GA, Stimac JA. 1990. Trace-element partitionning in pantellerites and trachytes. Geochim. Cosmochim. Acta, 54: 2257-2276.

Mbowou GIB, Ngounouno I, Deruelle B. 2010. Pétrologie du volcanisme bimodal du Djinga Tadorgal (Adamaoua, Cameroun). Rev. Cames, 11: 36-42.

N'ni J. 2004. Magmatogenèse du versant sudouest des Monts Bambouto-Bamenda (Ligne du Cameroun): géologie, volcanologie et pétrogenèse. Thèse d'État Université de Yaoundé-I p. 208.

Ngounouno I, Déruelle B, Demaiffe D, Montigny R. 1997. Données nouvelles sur le volcanisme cénozoïque du fossé de 
Garoua (Nord du Cameroun). C.R. Acad. Sci. Paris, 325: 87-94.

Ngounouno I, Déruelle B, Demaiffe D, Montigny R. 2003. Petrology of the Cenozoic volcanism in the Upper Benue valley, northern Cameroon (Central Africa). Contrib. Mineral. Petrol., 145: 87-106.

Nicholls J, Carmichael JSE. 1969. Peralkaline acid liquids: A petrological study. Contrib. Mineral. Petrol., 20: 268-294.

Njonfang E, Nono A. 2003. Clinopyroxene from some felsic alkaline rocks of the Cameroun Line, central Africa: petrological implications. Eur. J. Mineral., 15: 527-542.

Nkouandou OF, Ngounouno I, Déruelle B, Ohnenstetter D, Montigny R, Demaiffe D. 2008. Petrology of the Mio-Pliocene volcanism to the North and East of Ngaoundéré (Adamawa, Cameroon). C.R. Geoscience, 340: 28-37.

Nkoumbou C, Déruelle B, Velde D. 1995. Petrology of $\mathrm{Mt}$ Etinde nephelinite series. J. Petrol., 36: 373-395.

Nkoumbou C. 1990. Etude géologique des Monts Roumpi: un ensemble plutonique et volcanique de la Ligne du Cameroun. Données pétrologiques sur les néphélinites du Mont Etinde (Cameroun). Thèse Doctorat, Université de Nancy 1, p. 355.

Pouchou JL, Pichoir F. 1991. Quantitative analysis of homogeneous or stratified microvolumes applying the model «PAP». In: Electron Probe Quantification, Heinrich KFJ, Newbury DE (eds). Plenum Press: New York; 3175.

Ren M, Onenda PA, Anthony EY, White JC, Macdonald R, Bailey DK. 2006. Application of the QUILF thermobarometer to the peralkaline trachytes and pantellerites of the Eburu volcanic complex, East African Rift, Kenya. Lithos, 91: 109-124.

Ronga F, Lustrino M, Marzoli A, Melluso L. 2010. Petrogenesis of a basaltcomendite-pantellerite rock suite: the Boseti Volcanic Complex (Main Ethiopian Rift). Mineral. Petrol., 98: 227-243.

Temdjim R, Njilah IK, Kamgang P, Nkoumbou C. 2004. Données nouvelles sur les laves felsiques de Ngaoundéré (Adamaoua, Ligne du Cameroun): chronologie $\mathrm{K}-\mathrm{Ar}$ et pétrologie. Afr. J. Sci. Techn., 5: 113-123.

White JC, Ren M, Parker DF. 2005. Variation in mineralogy, temperature, and oxygen fugacity in a suite of strongly peralkaline lavas and tuffs, Pantelleria, Italy. Can. Mineral., 43: 1331-1347. 